\title{
INNOVATION AND INNOVATIVE ACTIVITY IN EDUCATION
}

\author{
Ikramjon Mamajanov
}

Independent Researcher Tashkent State Pedagogical University, Uzbekistan

\section{ABSTRACT}

This article is focused on the meaning and content of innovation and innovative activity and the descriptions given to them by Uzbek scientists and scientists from foreign countries. Besides that the article comprises different opinions and approaches on the descriptions, attitudes articles given to "Innovation" and "Innovative activity" in the framework of the laws on "Innovative activity", "Education" and "Science and scientific activity".

KEYWORDS:- Innovation, innovative activity, innovative processes, economy of knowledge, digital economy, professional innovative activity.

\section{INTRODUCTION}

From the economic point of view, the study of international experience in the organization and support of innovative activities in the context of modern globalization, digital economy and the construction of a new Uzbekistan serves not only at the enterprise level but also in higher education.

From a pedagogical point of view, the innovative processes taking place in the modern education system are primarily related to the active use of digital technologies in all areas of human activity and are primarily aimed at improving the quality and efficiency of education. In this regard, the professional innovative activity of students has a radically different meaning. The essence and content of innovative activity is that any innovation in the field of education for students occurs when it is carried out by the teacher. That is, the transformation of students from object to subject in the educational process depends primarily on the professional competence of the teacher.

The Address of the President of the Republic of Uzbekistan to the Oliy Majlis acknowledges that our country has entered the stage of innovative development in order to achieve modern progress. "Innovation is the future. We need to start building our great future ... based on innovative ideas. It is no coincidence that we are moving towards innovative development and the digital economy. Because who will win in today's fast-paced world? A state based on a new idea, a new idea, innovation wins" [4].

"The adoption of the Law of the Republic of Uzbekistan "On Innovative Activity" (July 24, 2020) was an important step in building a new Uzbekistan in order to create the appropriate legal framework provided for in the State Program "Year of Science, Enlightenment and 
CURRENT RESEARCH JOURNAL OF PEDAGOGICS 2(9): 101-105,

September 2021 DOI: https://doi.org/10.37547/pedagogics-crjp-02-09-23

ISSN 2767-3278

(C)2021 Master Journals

Crossref do: 81 Google

Accepted 25 $5^{\text {th }}$ September, 2021 \& Published 30th September, 2021

Digital Economy". This law is extremely important in strengthening the reliable legal mechanisms for the creation and implementation of new ideas, new discoveries, scientific developments that guarantee and accelerate our development.

\section{Analysis of the relevant literature}

The Law of the Republic of Uzbekistan "On Innovative Activity" defines "innovation" and "innovative activity" as follows: - organization of new developments, as well as activities to ensure their implementation and implementation in the field of production [1].

"The concept of "innovation" began its new life in the early twentieth century in the scientific work of the Austrian economist J. Schumpeter as a result of the analysis of "innovative combinations", changes in the development of economic systems. Schumpeter was one of the first scientists to introduce the term into scientific use in economics in the 1900s. Based on his theory of "creative destruction", he studied innovative processes and suggested that entrepreneurs consider the use of existing products in the creation of new products and services as other modern methods [5].

English professors V.R. Spencer explains, "Innovation is something completely new in a real situation that we can use when we realize it" [9]. Russian scientists A. Kulagin describe "Innovation is innovation in innovation, production, institutional finance, science and technology and other areas" [14]. "Innovative opportunities are the constant discovery and use of combined knowledge," says D. Fori. At the same time, the main focus in the combined processes is knowledge "[9]. I. Balabanov said that "innovation is the material result of the introduction of capital into new equipment or technology, new forms of organization of production, labor, services and management, including new forms of control and accounting, methods of planning and analysis" described.

[10]

J. Yuldashev: "Innovation (from the English" Innovation ") is a key part of the practice and theory of changing the internal structure of the system, and innovative activity is" incompatibility of traditional norms with new social requirements. " An activity aimed at resolving the complex problems that have arisen as a result of the conflict between the updated norms of practice and existing norms "[2]. Researcher E. Gaffarov described "Innovation is a novelty that highlights the practical significance of the invention and ensures its success" [11]. Innovative activity is first and foremost an activity. This activity is both an economic and a social activity. While economic activity is mainly associated with the modernization of production of enterprises, social activity is characterized by the introduction and introduction of innovations in this social sphere. This activity is also related to research and creativity in creating or implementing innovations.

\section{RESEARCH METHODOLOGY}

In this work, the legal and regulatory framework for preparing students for innovative activities, priorities for improving and developing the mechanism of preparing students for professional innovative activities, ensuring the quality and effectiveness of innovative and modern information technologies in preparing for professional innovative activities, nontraditional methods of economic education. A systematic approach and analytical methods were used throughout the study.

\section{AnAlysis AND RESUltS}

At the same time, it should be noted that there are a number of shortcomings in innovation. First, the interaction between the ministries and agencies responsible for the development of 
CURRENT RESEARCH JOURNAL OF PEDAGOGICS 2(9): 101-105,

September 2021 DOI: https://doi.org/10.37547/pedagogics-crjp-02-09-23

ISSN 2767-3278

(C)2021 Master Journals

Crossref do: 81 Google

Accepted 25 $5^{\text {th }}$ September, 2021 \& Published 30 ${ }^{\text {th }}$ September, 2021

scientific and innovative activities is not adequate, and the activities of research institutions and laboratories are not properly coordinated; second, the low level of commercialization of scientific results; third, the lack of highly qualified specialists capable of actively promoting and implementing technology transfer in the field of innovation management; fourth, the state funding of scientific and innovative activities is inefficient and transparent, and there are no mechanisms to encourage the attraction of extra-budgetary and private funds.

In order to overcome these problems, the legal framework for the development and promotion of innovative activities in the Republic has been created. Law of the Republic of Uzbekistan "On Innovative Activity" (24.07.2020, ZRU-630), Strategy of innovative development of the Republic of Uzbekistan for 2019-2021 (No. PF5544 of 21.09.2018), Science and Technology of the Republic of Uzbekistan Law of the Republic of Uzbekistan "On scientific activity" (29.10.2019, N ORQ-576). [1, 3]

The Law "On Innovative Activity" defines the concepts of innovation, innovative infrastructure, innovative project, innovative activity, the state order for the creation of innovations, technology transfer, new development. In particular, "innovation is a new development that is introduced into civil circulation or used for personal needs, the application of which in practice provides great socio-economic benefits." supply activities "[1].

It should be noted that as a result of the rapid development of innovation processes in the Republic, there is a need for innovative infrastructure. Innovative infrastructure is a set of enterprises, organizations, institutions, their associations of any form of ownership, which provide material, technical, financial, organizational and methodological, informational, consulting and other aspects of innovative activity. At the same time, the Republic has formed an innovative infrastructure in the field of education, as in all areas. We can see the formation of this infrastructure directly in the changes in the types of education.

Article 8 of the Law "On Education" is devoted to "Preschool education and upbringing", which provides for the education and upbringing of children, their intellectual, spiritual, moral, ethical, aesthetic and physical development, as well as the preparation of children for general secondary education. is a type of focused education. " This type of education also includes one year of compulsory preparation of children between the ages of six and seven for primary education. Article 9 of the law is devoted to "General secondary and secondary special education", which provides for primary education in grades 1-4, basic secondary education in grades 4-9 and grades 10-11. [3]

Another change is professional training. Vocational education is reflected in Article 10 of the Law, which is divided into primary vocational education, secondary vocational education and secondary special vocational education. While primary vocational education is provided in vocational schools on the basis of 9th grade graduates free full-time integrated programs for two years, in secondary vocational colleges general secondary, secondary special secondary education in full-time, part-time and part-time forms of education up to two years as well as on the basis of primary vocational education.

Secondary special vocational education is provided on the basis of general secondary, secondary special, primary vocational and secondary vocational education on the basis of state order or contract, depending on the complexity of professions and specialties, fulltime, part-time and distance learning.

Higher education provides training of highly 
CURRENT RESEARCH JOURNAL OF PEDAGOGICS 2(9): 101-105,

September 2021 DOI: https://doi.org/10.37547/pedagogics-crjp-02-09-23

ISSN 2767-3278

(C)2021 Master Journals

\section{Crossref do) 8 Google}

Accepted 25 $5^{\text {th }}$ September, 2021 \& Published $30^{\text {th }}$ September, 2021

qualified personnel in bachelor's and master's specialties (Article 11). At the same time, Article 15 of the Law states that the forms of education include: full-time education (full-time); education inseparable from production (correspondence, evening, distance); dual education; family education and independent study; teaching and educating adults; inclusive education; external education; training in the field of defense, security and law enforcement. [3]

Article 31 of the law stipulates that the activities of non-governmental educational organizations must be carried out on the basis of a license, and that non-governmental educational organizations must provide educational services in accordance with the requirements and conditions of the license. Another noteworthy aspect of the Law on Education is reflected in its Article 36. Article 36, entitled "Experimental and innovative activities in the field of education", recognizes that "experimental and innovative activities in the field of education are aimed at modernizing education and developing, testing and introducing new educational technologies and resources into the educational process." are given. This article is aimed at the organization of innovative activities in the education system. opportunities will be created for the gradual transition to more advanced forms of the process $"[3]$.

\section{Conclusions AND Suggestions}

The rapid introduction of modern innovative technologies in the economy, social and other spheres with the widespread use of scientific and technical achievements is an important condition for the rapid development of the Republic of Uzbekistan. In this regard, the Law of the Republic of Uzbekistan "On Science and Scientific Activity" (29.10.2019 N ORQ-576) was adopted, which regulates relations in the field of science and scientific activity. The law is important in that it focuses directly on the development of science on the basis of innovative activities for research entities. Chapter 19 "Priorities for the development of science and technology" states that "Priorities for the development of science and technology are the achievement of competitiveness and efficiency of the national economy, increasing labor productivity, creating new industries, living standards, quality of science and education." It is designed to provide a scientific solution to the problems associated with the development of "[3]. This, in turn, allows for innovative activities.

Based on the above, it is advisable to do the following:

- Knowledge required to understand the content and essence of the concepts of "innovation" and "innovative activity" in society. Expanding the scope of arming with skills and competencies;

- Further acceleration of work on publicizing the content and essence of the newly adopted Law "On Education";

- Emphasis on innovative activities in the development of all areas, with the establishment of a knowledge-based innovative economy as the basis for building a new Uzbekistan;

- Ensuring the rapid development of socioeconomic relations between the subjects of innovative infrastructure, such as innovation technology park, technology transfer center, innovation cluster, venture organization, innovation center;

- As a result of systematic organization of the activities of innovation clusters, innovation activity in the Republic will be further developed and, as a result, the quality and efficiency of innovation activity will be ensured. New innovations emerge, people 
CURRENT RESEARCH JOURNAL OF PEDAGOGICS 2(9): 101-105,

September 2021 DOI: https://doi.org/10.37547/pedagogics-crjp-02-09-23

ISSN 2767-3278

(C)2021 Master Journals

Crossref dof 81 Google

Accepted 25th September, 2021 \& Published 30 ${ }^{\text {th }}$ September, 2021

strive for innovation..

\section{REFERENCES}

1. Law of the Republic of Uzbekistan "On Innovative Activity". No. ORQ-630.

2. Law of the Republic of Uzbekistan "On Education". 23.09.2020 No. ZRU-637.

3. Law of the Republic of Uzbekistan "On science and scientific activity". No. ORQ-576.

4. Mirziyoev Sh.M. Address of the President of the Republic of Uzbekistan to the Oliy Majlis. - T.2018, pages 19-20.

5. Schumpeter J. Theory of economic development. M., Direct-Media, 2007.4.

6. Santo B. Innovation and global intellectualism // Innovations. - 2006. - No. 9; 5 .

7. Fatkhutdinov R. Innovation management. 6th ed. - SPb .: Peter, 2008.

8. Kondratyev N.D. Problems of economic dynamics. - M .: Economics, 1989;

9. Innovation: theory, mechanism, government regulation: Textbook. allowance / Ed. Yu.V. Yakovets. - M .: RAGS, 2000.

10. Balabanov I. Innovative management. Peter, 2001.

11. Kantorovich L. Sitemny analysis and nektorie problem of scientific and technical progress. M.: Nauka, 1986.

12. Yuldashev J.G., Usmonov S. A. Fundamentals of pedagogical technology: Manual. - $\mathrm{T}$.: Teacher, 2004. - 104 p.

13. G'affarov E. Innovation, social innovation and innovation activity: scientific-theoretical approaches. Scientific bulletin of NamSU.
2019, No. 10. Pages 153-157.

14. Kulagin A. Assessment and self-assessment of a scientific organization. Innovative economy. 2011 Art. 54-55. 